\title{
CAN ARAUCARIA FOREST REMNANTS REGENERATE AFTER 70 YEARS OF ANIMAL HUSBANDRY? A CASE STUDY ON CAÍVAS IN SOUTHERN BRAZIL
}

\author{
Ana Lúcia Hanisch ${ }^{1 *}$, Maria Izabel Radomski in memorian ${ }^{2}$. André Eduardo Biscaia de Lacerda ${ }^{2}$ \\ ${ }^{1}$ Empresa de Pesquisa Agropecuária e Extensão Rural de Santa Catarina, Estação Experimental de Canoinhas, Canoinhas, Santa Catarina, \\ Brasil - analucia@epagri.sc.gov.br \\ ${ }^{2}$ Embrapa Florestas, Colombo, Paraná, Brasil - andre.biscaia@embrapa.br \\ Received for publication: 08/01/2019 - Accepted for publication: 30/04/2019
}

\begin{abstract}
Resumo
Os remanescentes de Floresta de Araucária conseguem se regeneram mesmo após 70 anos de uso com pastejo animal? Um estudo de caso nas caívas no Sul do Brasil. No sul do Brasil, os fragmentos florestais são comumente utilizados como sistemas agroflorestais (SAFs) - chamados de caívas - focados na produção de erva-mate e na pecuária. Embora as caívas ajudem a manter a cobertura florestal, há uma falta geral de compreensão dos efeitos desse sistema sobre a diversidade de espécies e seu potencial para restauração ecológica. Com o objetivo de contribuir para o melhor entendimento da dinâmica florestal (árvores e regeneração) destes SAFs, apresentamos um estudo de caso que avalia, ao longo de um período de seis anos, uma área de caíva utilizada há 70 anos com a pecuária. Observamos que o manejo florestal na caíva altera a estrutura populacional principalmente através da redução da densidade de algumas espécies de árvores adultas. Por outro lado, a regeneração potencial mostra crescimento consistente, incluindo várias espécies não encontradas na população adulta. A regeneração florestal encontrada nas caívas mostrou grande resiliência, apesar do uso extrativo desses remanescentes por muito tempo. Este resultado pode ser usado para restaurar florestas com uma cobertura florestal densa e diversificada dentro das áreas caívas. Com o manejo correto deste potencial de regeneração é possível manter florestas saudáveis e diversificadas, sendo conservadas através do uso.

Palavras-chave: sistema silvipastoril, manejo florestal tradicional, Ilex paraguariensis, conservação pelo uso.
\end{abstract}

\begin{abstract}
In Southern Brazil, forest fragments are commonly used for agroforestry systems (AFS) - called caívas focused on erva-mate and livestock production. Although the caivas have helped maintain forest cover, there is a general lack of understanding of the effects of this system on species diversity and their potential for ecological restoration. Aiming to contribute to a better understanding of the forest dynamics (trees and regeneration) of these AFS, we present a six-year case study in which we monitored a caivva that has been used for animal husbandry for 70 years. We observe that forest management in the caíva modified the population structure mostly through reductions in the density of a few adult tree species. On the other hand, the potential regeneration shows consistent growth, including several species not found in the adult population. The caiva showed high levels of resilience in terms of regeneration, despite the extractive use of these remnants over several decades. This result demonstrates that the strategies used herein can help to restore forests with a dense and diverse forest cover within caivas. With the correct management of this regeneration potential, it is possible to maintain healthy and diverse forests that are being conserved through use.
\end{abstract}

Keywords: silvopastoral systems, traditional forest management, Ilex paraguariensis, conservation by use.

\section{INTRODUCTION}

Due to its economic, ecological, and cultural benefits, agroforestry is an important land use strategy that has been implemented worldwide (FAO, 2016) and may include systems with the presence of grazing animals (PIGNATARO et al., 2016).

Over generations, communities have developed Traditional Ecological Knowledge (TEK), enabling them to implement forest management practices that combine sustainability of food resources and healthy forests with various crops, trees, and animal husbandry (MICHON et al., 2007). Although agroforestry practices may be important for biodiversity conservation, antagonism towards traditional management systems remains as these systems are viewed as being in conflict with nature conservation (REIS et al., 2013; LACERDA, 2016). The intense degradation of some ecosystems, combined with a resistance to incorporate TEK into environmental policies, have prevented or even prohibited small-scale farmers from managing forests through agroforestry systems (MICHON et al., 2007, LACERDA 2016).

In this context, we present a case study to assess the long-term sustainability of one traditional agroforestry system in Southern Brazil - caívas - an agroforestry system based on the production of erva-mate

FLORESTA, Curitiba, PR, v. 50, n. 3, p. 1537 - 1546, jul/set 2020.

Hanisch, A. L. et.al.

ISSN eletrônico 1982-4688

DOI: 10.5380/rf.v50 i3. 64248 
and bovine husbandry (HANISCH et al., 2010). Because the management of forests is integral to caívas, landowners have maintained forest cover that varies in terms of canopy cover, forest structure, and diversity, and management strategies depend directly on the production objectives of the farm (MELLO and PERONI, 2015). Several authors have suggested that the remaining forest fragments found in Southern Brazil continue to exist because traditional systems have protected the forests (REIS et al., 2013, PINOTTI et al., 2018).

As an agroforestry system, caivas are poorly understood, although the presence of animals is generally regarded as having a negative impact on the maintenance of forest biodiversity (SOUZA et al., 2010, VIBRANS et al., 2011).

Considering that caivas have historically been able to self-perpetuate within native forest cover in Southern Brazil, these systems likely play a crucial role in the conservation of forest fragment biodiversity (HANISCH et al., 2016). From this perspective, understanding the regenerative processes of the tree component among different caíva management strategies is an important consideration, since behavioral responses observed in the regeneration after disturbances informs the development of indicators for restoration (KANIESKI et al., 2012). However, the long-term sustainability of this agroforestry system has yet to be assessed.

In this context, this study aimed to provide a better understanding of the forest dynamics (trees and regeneration) in response to animal grazing of the herbaceous stratum in a caíva on a rural property in the Northern Plateau of Santa Catarina State, Brazil. Specifically, we sought to verify if there were differences in structure and diversity over a period of six years, assess changes over time, and ultimately infer the long-term sustainability of caívas. We also assessed the environmental resilience of caívas in terms of regeneration capacity of the managed forest fragment without the presence of animals. Based on the results obtained, we discuss the possibilities for conservation and sustainable use of these remnants to maintain healthy and diverse forests while they continue to be used for productive purposes.

\section{MATERIAL AND METHODS}

\section{Characterization of the study area}

This case study was carried out on a small-scale farm with a typical caíva system in Canoinhas (26 $13^{\prime} 23^{\prime \prime}$ $\mathrm{S}$ and $50^{\circ} 27^{\prime} 7^{\prime}$ W, climate Cfb, $810 \mathrm{~m}$ above sea level), Santa Catarina State, Brazil. The landscape is characterized by gently undulating terrain with a predominance of Oxisols.

The 22 ha rural property is an intermixed mosaic of land use including agriculture, animal husbandry, agroforestry, and commercial forest plantations. The farm has a variety of productive systems including annual crops (soy and corn), dairy cow production in managed pastures, and a 10 ha caíva with native erva-mate trees and dairy cow grazing. The caíva has been managed for at least 70 years, with no pasture division management and a mean annual stocking rate of $0.4 \mathrm{AU} / \mathrm{ha}$ (animal unit $=500 \mathrm{~kg}$ live weight).

The forest in the caiva has never been clear-cut, although selective logging took place approximately 20 years ago and focused on valuable timber species (Araucaria angustifolia and Ocotea porosa, among others). The understory is cleared annually by mowing (particularly to manage the abundant, fast-growing tree Curitiba prismatica), to facilitate erva-mate harvesting and animal grazing. Periodically, trees are pruned or removed to provide light for pasture and erva-mate development.

\section{Data collection and analysis}

We monitored the adult population (diameter at breast height $=\mathrm{dbh} \geq 5 \mathrm{~cm})$ in a $4320 \mathrm{~m}^{2}(60 \times 72 \mathrm{~m})$ plot within in the caiva, where we identified and measured the total height and dbh of all trees in 2010, 2013, and 2015.

In the same area, three randomly distributed plots of $160 \mathrm{~m}^{2}(8 \times 20 \mathrm{~m})$ were fenced, where monitoring of natural regeneration was conducted. The plots were fenced to protect seedlings from animal grazing and mowing/trimming. In these three plots, the seedlings (height $\geq 5 \mathrm{~cm} ; \mathrm{dbh} \leq 5 \mathrm{~cm}$ ) were tagged and monitored in 2010 (six months after the plots were fenced), 2012, 2013, and 2015. Seedlings were categorized into size classes (H) using a modified system based on Finol (1971): class $1=0.05>\mathrm{H}<1.49 \mathrm{~m}$; class $2=1.50>\mathrm{H}<3 \mathrm{~m}$; and class $3=\mathrm{H}>3.01 \mathrm{~m}$ to $5 \mathrm{~cm} \mathrm{dbh}$.

For both adult and regenerating trees the botanical identification was conducted in the field and samples were collected for confirmation and curation in the herbarium of Escola de Florestas de Curitiba (EFC) of the Federal University of Paraná (UFPR). Scientific names were based on the APG IV system (ANGIOSPERM PHYLOGENY GROUP 2016). Confirmation of the species found and an update of their botanical nomenclatures were carried out using the Tropicos and Flora Brasil (2016) websites. Information on successional status and those related to the species dispersion syndrome were obtained in Meyer et al., (2013). Following Budowski (1965), we classified species into ecological groups as pioneer, secondary, and late successional.

We used EstimateS v9.1 (COLWELL 2013) to calculate species richness (S), number of shared species between years (Sshared; without replacement configuration), and number of species exclusive to each year (Excl).

FLORESTA, Curitiba, PR, v. 50, n. 3, p. 1537 - 1546, jul/set 2020.

Hanisch, A. L. et.al.

ISSN eletrônico 1982-4688

DOI: $10.5380 /$ rf.v50 i3. 64248 


\section{RESULTS}

\section{Adult tree species diversity and structure}

During the six-year monitoring of the caiva system, 23 tree species were recorded with varying levels of total diversity over time. Specifically, a 14\% reduction in richness was observed in the first interval (2010-2013) after which the level of diversity remained stable (2013-2015; Figure 1). Concurrent with the variation in species diversity, the number of trees decreased during the analysis although with a much more evident reduction $(-34 \%)$ in 2013 after which a subtle negative trend was recorded in 2015 (-4\%; Table 1).

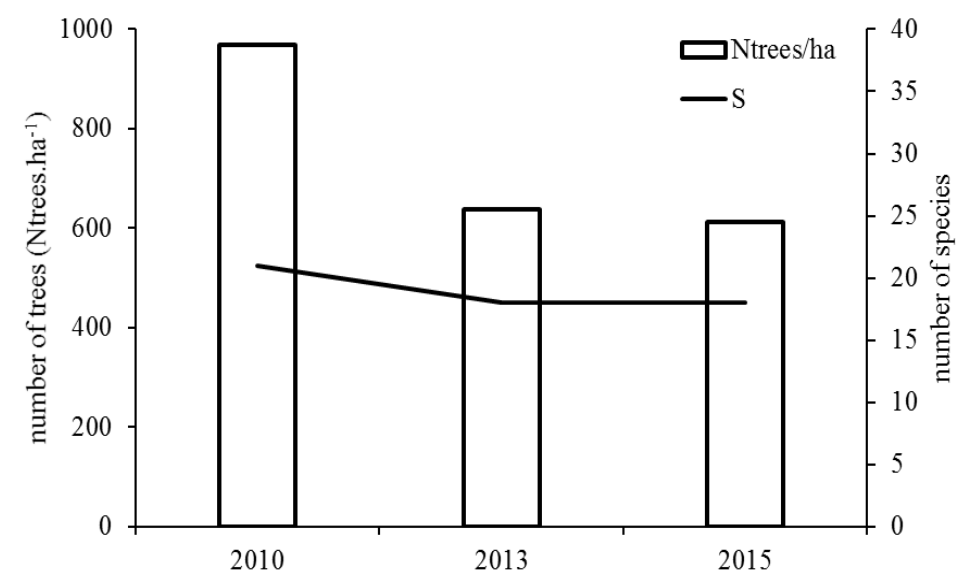

Figure 1. Variation of tree species density (N trees/ha) and richness (S) in a caíva system between 2010 and 2015 (Canoinhas, Santa Catarina State, Southern Brazil).

Figura 1. Variação da densidade (N trees/ha) e riqueza (S) de espécies arbóreas em uma caíva entre 2010 e 2015 (Canoinhas, Santa Catarina, Sul do Brasil).

Table 1. Floristic composition, density by species and ecological group, and dynamics in the density of trees and ecological group, in a caíva system between 2010 and 2015 (Canoinhas, Santa Catarina State, Southern Brazil).

Tabela 1 Composição florística, densidade por espécie e por grupo ecológico e dinâmica na densidade de árvores em uma área de caíva entre 2010 e 2015 (Canoinhas, Santa Catarina, Sul do Brasil).)

\begin{tabular}{|c|c|c|c|}
\hline SPECIES NAME & 2010 & 2013 & 2015 \\
\hline & \multicolumn{3}{|c|}{$\left(\right.$ N.ha $\left.^{-1}\right)$} \\
\hline Ilex paraguariensis A.St.-Hil. (S) & 543 & $463(-15 \%)^{*}$ & $412(-11 \%)$ \\
\hline Curitiba prismatica (D.Legrand) Salywon \& Landrum (S) & 203 & $100(-51 \%)$ & $116(16 \%)$ \\
\hline Annona neosalicifolia H.Rainer (S) & 111 & $31(-72 \%)$ & $33(6 \%)$ \\
\hline Ilex theezens Mart. ex Reissek (S) & 44 & $0(-100 \%)$ & $0(0 \%)$ \\
\hline Sapium glandulosum (L.) Morong (P) & 33 & $21(-37 \%)$ & $23(10 \%)$ \\
\hline Ilex brevicuspis Reissek (S) & 31 & $13(-57 \%)$ & $13(0 \%)$ \\
\hline Ocotea porosa (Nees \& Mart.) Barroso (L) & 28 & $31(12 \%)$ & $31(0 \%)$ \\
\hline Casearia decandra Jacq. Guaçatunga (S) & 21 & $5(-74 \%)$ & $5(0 \%)$ \\
\hline Araucaria angustifolia (Bert.) O. Kuntze (C) & 8 & $8(0 \%)$ & $8(0 \%)$ \\
\hline Nectandra lanceolata Nees (S) & 8 & $13(71 \%)$ & $10(-25 \%)$ \\
\hline Allophylus edulis (A.St.-Hil. et al.) Hieron. ex Niederl.(S) & 8 & $3(-63 \%)$ & $3(0 \%)$ \\
\hline Gymnanthes klotzschiana Müll.Arg. (S) & 5 & $0(-100 \%)$ & 0 \\
\hline Drimys brasiliensis Miers (S) & 5 & $3(-40 \%)$ & $3(0 \%)$ \\
\hline Campomanesia xanthocarpa (Mart.) O.Berg (S) & 5 & $0(-100 \%)$ & 0 \\
\hline Zanthoxylum rhoifolium Lam. (S) & 5 & $0(-100 \%)$ & 0 \\
\hline Cinnamodendron dinisii Schwacke $(\mathrm{P})$ & 5 & $3(-40 \%)$ & $3(0 \%)$ \\
\hline Cedrela fissilis Vell. (S) & 3 & $3(0 \%)$ & $3(0 \%)$ \\
\hline Myrceugenia myrcioides (Cambess.) O.Berg (L) & 3 & $8(166 \%)$ & $8(0 \%)$ \\
\hline Agonandra brasiliensis Miers ex Benth. \& Hook.f. (S) & 3 & $3(0 \%)$ & $3(0 \%)$ \\
\hline Syagrus romanzoffiana (Cham.) Glassman (P) & 3 & $3(0 \%)$ & $3(0 \%)$ \\
\hline
\end{tabular}

FLORESTA, Curitiba, PR, v. 50, n. 3, p. 1537 - 1546, jul/set 2020.

Hanisch, A. L. et.al.

ISSN eletrônico 1982-4688

DOI: $10.5380 /$ rf.v50 i3. 64248 
Eugenia uniflora L. (L)

Ocotea puberula (Rich.) Nees (P)

Prunus brasiliensis (Cham. \& Schltdl.) D.Dietr.

\begin{tabular}{|c|c|c|c|}
\hline TOTAL & 1075 & $710(-34 \%)$ & $679(-4 \%)$ \\
\hline \multicolumn{4}{|c|}{ ECOLOGICAL GROUP } \\
\hline Late successional (L) & 41 & $41(0 \%)$ & $41(0 \%)$ \\
\hline Secondary $(\mathrm{S})$ & 1001 & $648(-35 \%)$ & $615(-5 \%)$ \\
\hline Pioneer $(\mathrm{P})$ & 33 & $21(-36 \%)$ & $23(11 \%)$ \\
\hline
\end{tabular}

$\left(\mathrm{N} \cdot \mathrm{ha}^{-1}\right)=$ number of arboreal individuals per hectare; $\left(\mathrm{N} \cdot \mathrm{ha}^{-1}\right)=$ número de indivíduos arbóreos por hectare

* Numbers in parentheses, percentage change in density relative to the previous evaluation;

* números entre parênteses, percentagem de mudança de indivíduos na densidade em relação à avaliação anterior

Despite the negative general trend in the number of trees, changes in density affected each species differently. Ilex paraguariensis (the species with greatest density throughout the analysis) showed a relatively small reduction (between 11 and 15\%) while $C$. prismatica (second in density) had its population reduced by $51 \%$ in 2013 with a 16\% increase by 2015 (Table 1). In 2015, most species showed no change in density, three species presented increased density, and I. paraguariensis and Nectandra lanceolata showed a population reduction. Despite such variation, the species relative density did not change significantly between years and species with greater densities (i.e., species that account for at least $50 \%$ of the total number of trees) remained stable.

The species density dynamics in relation to ecological group showed that pioneer and secondary species were particularly affected in the first period $(-37 \%$ and $-35 \%$, respectively; Table 1$)$. During the second monitoring period, these groups showed divergent trends with less dramatic changes. Late successional species presented an initial increase $(17 \%)$ after which the population remained stable.

In relation to forest structure, the community showed relatively stable patterns of dbh and height distribution. We observed a concentration of trees in the dbh class between 5 and $20 \mathrm{~cm}$ and a dominance of trees in the lower height classes (Figure 2). The overall distribution of trees in the lower height categories showed a negative trend towards higher classes resembling a negative exponential distribution (LIOCOURT 1898; MEYER 1952). Ninety-one percent of the trees in the lowest height class are I. paraguariensis, which are maintained at heights suitable for harvesting, demonstrating a clear absence of diversity in the lowest height class which is not seen in the other classes.
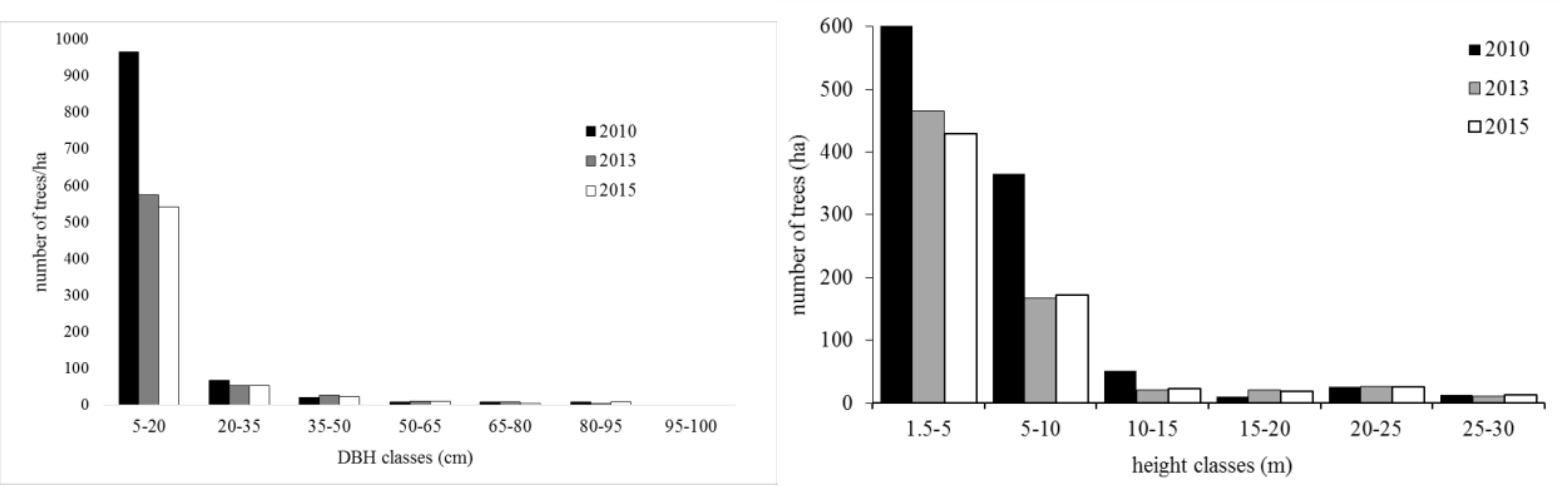

Figure 2. Tree community distribution by dbh (left) and height class (right) in a caíva system between 2010 and 2015 (Canoinhas, Santa Catarina State, Southern Brazil).

Figura 2. Distribuição da comunidade de árvores por DAP (esquerda) e classe de altura (direita) em uma caíva entre 2010 e 2015 (Canoinhas, Santa Catarina, Sul do Brasil).

\section{Natural regeneration diversity and structure}

A significant increase in the number of tree seedlings in the plots fenced-off from cattle grazing was observed during the evaluation, indicating a substantial resilience of the tree component in the caívas. During the six years in which the plots remained fenced, without animal access or mowing, 46 tree species were registered, and only one did not belong to the native vegetation of the Araucaria Forest (Table 2).

The species richness of the regeneration showed a continuous increase over the study period, from 21 species in 2010 to 37 in 2013, with a small reduction in 2015, when 31 species were observed. The density showed similar trends to richness, with the most significant increase in the period between 2012-2013, in which we identified a positive variation of $104 \%$, while in the other two periods (2010-2012 and 2013-2015), increases in density varied at much lower rates (21 and 15\%, respectively; Table 2). 
Table 2. Floristic composition and density by species and ecological group of forest regeneration in a caíva system without animal access or mowing, between 2010 and 2015 (Canoinhas, Santa Catarina State, Southern Brazil).

Tabela 2. Composição florística, densidade por espécie e por grupo ecológico da regeneração florestal em uma área de caíva sem acesso dos animais ou da prática da roçada, entre 2010 e 2015 (Canoinhas, Santa Catarina, Sul do Brasil).

\begin{tabular}{|c|c|c|c|c|}
\hline \multirow[t]{2}{*}{ SPECIES NAME (common name) } & 2010 & 2012 & 2013 & 2015 \\
\hline & \multicolumn{4}{|c|}{ Density $\left(\mathbf{N}^{-h a^{-1}}\right)$} \\
\hline Allophylus edulis (vacum) & $833^{1}$ & $792^{1}$ & $1542^{1}$ & $1438^{1}$ \\
\hline Zanthoxylum rhoifolium (mamica-de-cadela) & $750^{2}$ & $646^{2}$ & $708^{3}$ & $833^{3}$ \\
\hline Myrceugenia spp. (guamirim) & $292^{3}$ & $167^{7}$ & $271^{9}$ & 208 \\
\hline Ocotea puberula (canela-guaicá) & $250^{4}$ & $375^{4}$ & $1188^{2}$ & $604^{6}$ \\
\hline Ilex theezans (congonha) & $188^{5}$ & $208^{5}$ & $458^{6}$ & 125 \\
\hline Lonchocarpus spp. (timbó) & $146^{6}$ & $104^{9}$ & 42 & $583^{7}$ \\
\hline Mimosa scabrella (bracatinga) & $125^{7}$ & $104^{9}$ & 188 & 167 \\
\hline Curitiba prismática (cerninho) & $104^{8}$ & $125^{8}$ & $250^{10}$ & $750^{4}$ \\
\hline Anonna spp. (ariticum-preto) & $83^{9}$ & 21 & 104 & $292^{10}$ \\
\hline Cupania vernalis (cuvatã) & $83^{10}$ & $479^{3}$ & $354^{7}$ & $625^{5}$ \\
\hline Ilex paraguariensis A.St.-Hil. (erva-mate) & 83 & 0 & 21 & 0 \\
\hline Vachellia caven (Molina) Seigler \& Ebinger (espinilho) & 83 & 0 & 63 & 0 \\
\hline Gymnanthes klotzschiana Müll.Arg. (branquilho) & 42 & 0 & 0 & 0 \\
\hline Cedrela fissilis Vell. (cedro) & 42 & $104^{9}$ & 104 & 354 \\
\hline Erythroxylum deciduum A.St.-Hil. (marmeleiro) & 42 & 0 & 42 & 0 \\
\hline Matayba elaeagnoides Radlk. (miguel-pintado) & 42 & 0 & $604^{4}$ & $604^{6}$ \\
\hline Sapium glandulosum (leiteiro) & 21 & $83^{10}$ & 21 & 83 \\
\hline Prunus brasiliensis (Cham. \&Schltdl.) D.Dietr. (pessegueiro-brabo) & 21 & 21 & 83 & 0 \\
\hline Cinnamodendron dinisii Schwacke (pimenteira) & 21 & 0 & 0 & 42 \\
\hline Podocarpus lambertii Klotzch ex Endl (pinheiro-bravo) & 21 & 0 & 0 & 0 \\
\hline Eugenia uniflora L. (pitanga) & 21 & 21 & 0 & 83 \\
\hline Araucaria angustifolia (Bertol.) Kuntze (araucária) & 0 & $104^{9}$ & 83 & 146 \\
\hline Ocotea silvestris Vattimo-Gil (canela-preta) & 0 & 42 & $271^{9}$ & 125 \\
\hline Myrsine umbellata Mart. (capororoca) & 0 & $167^{7}$ & $542^{5}$ & $1021^{2}$ \\
\hline Campomanesia xanthocarpa (Mart.) O.Berg (guabiroba) & 0 & 42 & 42 & 83 \\
\hline Casearia decandra Jacq. (guaçatunga-branca) & 0 & $188^{6}$ & 42 & $333^{9}$ \\
\hline Ocotea porosa (Nees \& Mart.) Barroso (imbuia) & 0 & 21 & 21 & 0 \\
\hline Guapira opposita (Vell.) Reitz (maria-mole) & 0 & $104^{9}$ & 0 & 0 \\
\hline Hovenia dulcis Thunb. (uva-japão) & 0 & 42 & 0 & 0 \\
\hline Eugenia uvalha Cambess. (uvaia) & 0 & 63 & 0 & 0 \\
\hline Annona neosalicifolia $\mathrm{H}$. Rainer (ariticum-amarelo) & 0 & 0 & 42 & 0 \\
\hline Schinus terebinthifolius Raddi (aroeira) & 0 & 0 & 42 & 42 \\
\hline Nectandra megapotamica (Spreng.) Mez (canela-imbuia) & 0 & 0 & 63 & 21 \\
\hline Dalbergia frutescens (Vell.) Britton & 0 & 0 & 42 & 0 \\
\hline Machaerium paraguariense Hassl. (farinha-seca) & 0 & 0 & 42 & 42 \\
\hline Casearia sylvestris $\mathrm{Sw}$. (guaçatunga-preta) & 0 & 0 & 21 & 208 \\
\hline Myrcia splendens (Sw.) DC. (guamirim-chorão) & 0 & 0 & $333^{8}$ & 0 \\
\hline Syagrus romanzoffiana (Cham.) Glassman (jerivá) & 0 & 0 & $333^{8}$ & 167 \\
\hline Acosmium lentiscifloium Schott (murta) & 0 & 0 & 21 & 0 \\
\hline Picramnia excelsa Kuhlm. ex Pirani (pau-amargo) & 0 & 0 & 42 & 83 \\
\hline Trichilia sp. (trichilha) & 0 & 0 & 63 & 0 \\
\hline Clethra scabra Pers. (carne-de-vaca) & 0 & 0 & 0 & 125 \\
\hline Eugenia involucrata DC. (cerejeira) & 0 & 0 & 0 & 42 \\
\hline Balfourodendron riedelianum (Engl.) Engl. (pau-marfim) & 0 & 0 & 0 & 42 \\
\hline Ocotea odorifera (Vell.) Rohwer (canela-sassafrás) & 0 & 0 & 0 & 21 \\
\hline Piptocarpha axillaris (Less.) Baker (vassourão-preto) & 0 & 0 & 0 & 21 \\
\hline TOTAL.ha ${ }^{-1}$ & 3292 & 4021 & 8104 & 9313 \\
\hline \multicolumn{5}{|c|}{ ECOLOGICAL GROUPS } \\
\hline Late successional & 313 & 208 & 688 & 354 \\
\hline Secondary & 2.854 & 3.417 & 6.625 & 7.500 \\
\hline Pioneer & 125 & 402 & 792 & 1.458 \\
\hline
\end{tabular}

FLORESTA, Curitiba, PR, v. 50, n. 3, p. 1537 - 1546, jul/set 2020.

Hanisch, A. L. et.al.

ISSN eletrônico 1982-4688

DOI: $10.5380 /$ rf.v50 i3. 64248 
$\left(\mathrm{N} . \mathrm{ha}^{-1}\right)=$ number of trees per hectare; superscript numbers refer to classification of the ten species with the highest density of individuals per year;

$\left(\mathrm{N} \cdot \mathrm{ha}^{-1}\right)=$ número de indivíduos arbóreos por hectare; números sobrescritos referem-se à classificação das dez espécies com maior densidade de indivíduos por ano

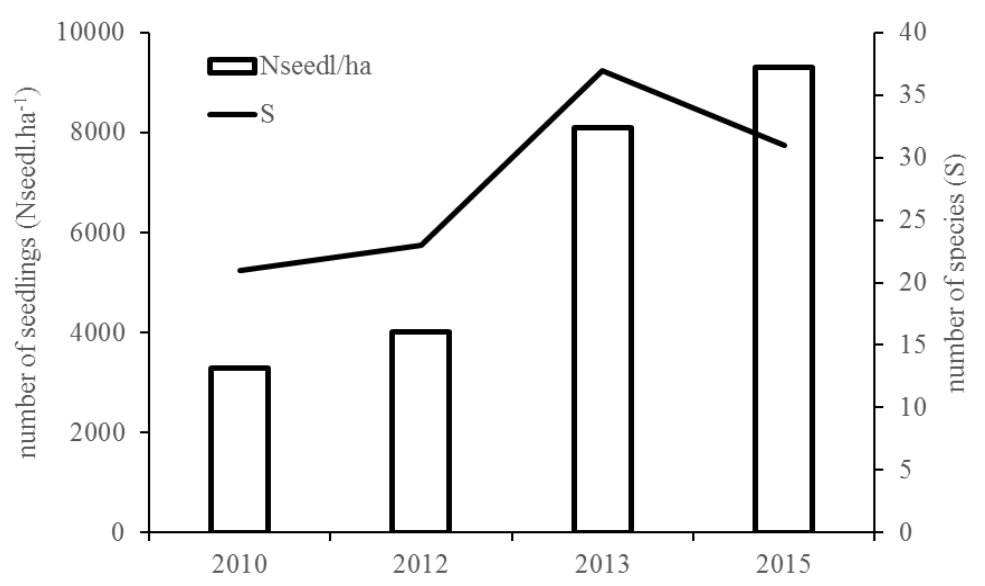

Figure 3. Density (Nseedl.ha $\left.{ }^{-1}\right)$ and richness (S) of forest species in the natural regeneration of a caíva system between 2010 and 2015 (Canoinhas, Santa Catarina State, Southern Brazil).

Figura 3. Densidade (Nseedl.ha-1 ${ }^{-1}$ e riqueza (S) de espécies florestais na regeneração natural em uma caíva entre 2010 e 2015 (Canoinhas, Santa Catarina, Sul do Brasil).

The absolute density of the species in the regeneration varied in relation to the initial community, although the same behavior was not observed for the relative density (Table 2). A species may maintain a stable absolute density during the study, but an increase or decrease in the density of other species may alter its relative density. Curiously, the species with the highest absolute density did not alter their relative density; Allophylus edulis maintained the highest density in all years (with a tendency to increased density), and Zanthoxylum rhoifolium remained as the third most dense. On the other hand, we observed an important variation in the population of several other species, consequently altering their relative abundance.

The concentration of height classes of the seedlings varied throughout the study, with most concentrated in the $<0.5 \mathrm{~m}$ class in 2010. The variation in height became greater in 2013, where several individuals exceeded the adult threshold $(1.5 \mathrm{~m})$ and by 2015 several plants reached heights of $8 \mathrm{~m}$ (Figure 4 ). The tallest plants were those of the pioneer ecological group (predominantly, Mimosa scabrella).

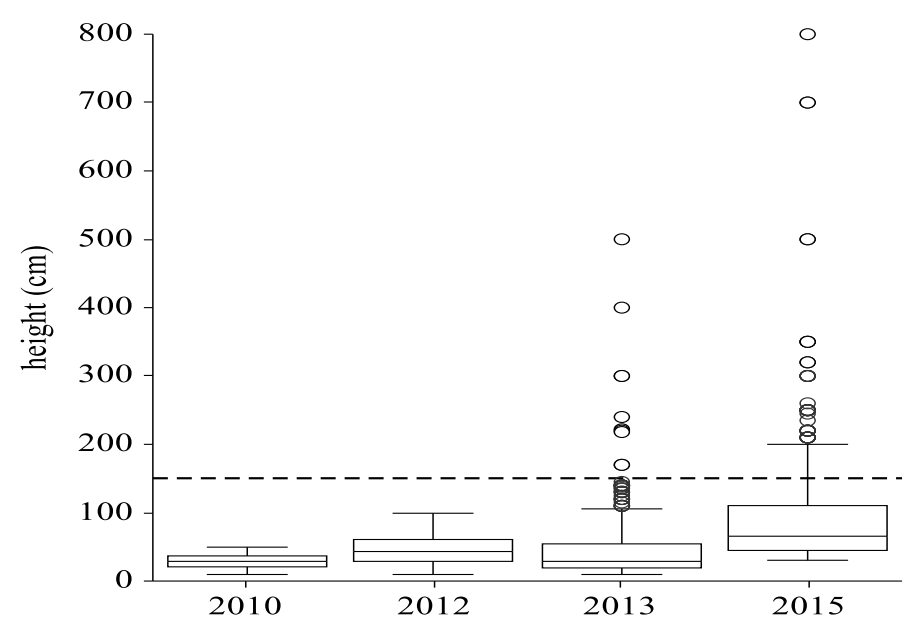

Figure 4. Distribution of the number of individuals.ha ${ }^{-1}$ by height $(\mathrm{cm})$ of the natural regeneration between 2010 and 2015 in caiva plots protected against animal grazing. Dashed line at $1.5 \mathrm{~m}=$ threshold above which plants are considered adults.

Figura 4. Distribuição do número de indivíduos.ha ${ }^{-1}$ por altura $(\mathrm{cm})$ da regeneração natural entre 2010 e 2015 em parcelas de caíva protegidas contra pastejo animal. Linha tracejada a $1,5 \mathrm{~m}=$ limiar acima do qual as plantas são consideradas adultos.

FLORESTA, Curitiba, PR, v. 50, n. 3, p. 1537 - 1546, jul/set 2020

Hanisch, A. L. et.al.

ISSN eletrônico 1982-4688

DOI: $10.5380 /$ rf.v50 i3. 64248 


\section{Comparison between natural regeneration and forest diversity and structure}

The diversity of shared species between regeneration and the adult population was stable for 12 species in all years, that is, between 30 and $42 \%$ of the diversity was found in both populations (Table 3 ).

The number of species unique to one component was always higher in the regeneration than adults. The adult population showed a more stable diversity, with a tendency for homogenization, since the number of exclusive species was zero between 2013 and 2015. In the regeneration, the diversity of species varied throughout the study, enabling us to observe a relatively large number of species not found in the years prior to 2015 .

Table 3. Comparison of species diversity of adult population (tree) and natural regeneration (seedl) in different years. Parameters: richness (S), exclusive number of species (Excl), number of shared species (Sshared), and total of number species in each comparison (Stotal).

Tabela 3. Comparação da diversidade de espécies da população adulta (árvore) e da regeneração natural (seedl) em diferentes anos. Parâmetros: riqueza (S), número exclusivo de espécies (Excl), número de espécies compartilhadas (Sshared) e número de espécies totais em cada comparação (Stotal).

\begin{tabular}{lllllll}
\hline YEAR COMPARISON & \multicolumn{9}{c}{ INDIVIDUAL YEAR PARAMATERS } & COMPARISON SUMMARY \\
\hline 1st term & \multicolumn{7}{c}{ 2nd term } \\
\hline 1st term x 2nd term & S1 & Exc1 & S2 & Exc2 & Sshared & Stotal \\
\hline Tree 2010 x Tree 2013 & 21 & 5 & 18 & 2 & 16 & 22 \\
Tree 2013 x Tree 2015 & 18 & 0 & 18 & 0 & 18 & 18 \\
Seed12010 x Seedl 2012 & 21 & 9 & 23 & 9 & 12 & 32 \\
Seedl2012 x Seedl2013 & 23 & 5 & 37 & 19 & 18 & 42 \\
Seedl2013 x Seedl2015 & 37 & 5 & 31 & 8 & 23 & 45 \\
Seedl 2010 x Tree 2010 & 21 & 9 & 21 & 7 & 12 & 28 \\
Seedl 2013 x Tree 2013 & 37 & 25 & 18 & 3 & 12 & 40 \\
Seedl 2015 x Tree 2015 & 31 & 19 & 18 & 3 & 12 & 34 \\
\hline
\end{tabular}

\section{DISCUSSION}

\section{Species diversity and structure in caívas}

The results for adult diversity (18-23 species) showed levels similar to those reported in the Santa Catarina Forest Inventory (SCFI; MEYER et al., 2013; plots), which confirms the important role of caívas in forest cover conservation in the state. The SCFI used sampling areas similar to those installed in this study (4000 and $4320 \mathrm{~m}^{2}$, respectively), and included managed and unmanaged forests, which should be sufficient to capture wide variations in richness.

Previous research has shown that the productive focus of a caiva (greater amount of erva-mate production or higher animal load) is the main factor that affects the diversity of species, with previously observed variations among caivas of 18 to 42 species.ha $^{-1}$ (HANISCH et al., 2010, PINOTTI et al., 2018).

The main productive focus of the studied caiva is erva-mate, which is economically valuable and a relevant component in the income of most small-scale properties in Southern Brazil. Erva-mate trees are traditionally harvested in three-year cycles and after several harvests (20-40 years), trees may require a radical pruning to increase yield (STUEPP et al., 2016). The results for 2013 show precisely the effects of this type of erva-mate management; the reduction in density reflects, in most cases, trees that were harvested (shifting to lower height classes) and dead trees that were removed (reducing density).

Another species that reflected the traditional management of caivas was Curitiba prismatica. Because it is a fast-growing species with a highly effective ability to disperse, sprout after cutting, and develop into dense clusters (LORENZI, 2014), its removal is a regular activity in the region and is seen as necessary to maintain the productive structure of the forest. Ilex theezans, which also showed a reduction in population, had a clustered distribution in the area (combined with its typically dense canopy) (LORENZI, 2014). Similar to C. prismatica, I. theezans is seen as an impediment to pasture development and erva-mate production. The lower levels of variation in density for other species may be related to less intensive interventions as well as natural mortality.

In the plots that were fenced off to protect against animal grazing and mowing, we observed a steady increase in the seedling population and an important increase in species diversity in relation to pre-fencing levels. Although several species showed fluctuations in their population over the six-year period, some species populations increased consistently among the regeneration, particularly A. edulis, C. prismatica, and Cupania vernalis. These secondary species are frequent in natural forests and tolerant to considerable shade levels

FLORESTA, Curitiba, PR, v. 50, n. 3, p. 1537 - 1546, jul/set 2020.

Hanisch, A. L. et.al.

ISSN eletrônico 1982-4688

DOI: $10.5380 /$ rf.v50 i3. 64248 
(VIBRANS et al., 2011) Although most of the population increase is concentrated within secondary species, we also found a stable increase in pioneer and late successional species (Table 2). These results indicate a likely transition from initial stages of forest regeneration to more diverse and structurally complex stages over the short study period (six years).

The richness of regeneration found in this study indicates a high level of resilience of the caiva trees and confirms that they have sufficient material legacies (for example, seeds, remaining trees, soil nutrients) and information legacies (species with adaptation to disturbance) (JOHNSTONE et al., 2016) to maintain productive forest communities. However, studies that confirm the adequate amount of regeneration in forest remnants submitted to anthropogenic actions there are still rare.

Finally, the occurrence of pioneer species among the regeneration with rapid growth $(>1.50 \mathrm{~m}$ in height by 2013) that surpassed the regeneration/adult threshold, indicates that enough light exists for them to thrive. Furthermore, the fastest growing plants ( $>3 \mathrm{~m}$ by 2013), considered to be established as viable trees, were secondary species, indicating that the environmental conditions (especially light) are favoring secondary over pioneer species, again suggesting a positive trend in the development of a complex and healthy forest.

\section{Implications for conservation and caíva development}

The regeneration dynamics identified herein show that caivas can be successfully managed to guarantee long-term sustainability. This involves the introduction of silvicultural practices to manage the regeneration and adult population, maintain a consistent forest canopy, and increase species diversity (favoring species not found in the forest canopy). Although the management of regeneration can prioritize secondary and late successional species due to their longer life cycles, strategies can also take advantage of rapidly growing pioneer species as a source of firewood to be consumed locally. This, in turn, provides economic diversity alternatives, which has been suggested as a path for sustainable rural development (VIEIRA et al., 2009). Additionally, appropriate silvicultural practices can take advantage of a species' inherent characteristics and create opportunities for local or commodity consumption. In this context, even C. prismatica - a species perceived as a problem - could be managed to produce tool shanks, an end use for which the species has been traditionally employed in the region.

Our results indicate a need to implement management practices that will maintain the tree cover in the long-term, which can be achieved by taking advantage of the system's inherent regeneration potential. Caívas have sufficient material legacies (e.g., seeds, remnant trees, soil nutrients) and information legacies (species with traits suited to disturbances) to maintain productive but diverse forest communities; as such, caivas are forests with relevant ecological memory (JOHNSTONE et al., 2016) that are capable of rapid recovery. Therefore, they play an important role in regional conservation (LACERDA 2016). The presence of species in the regeneration plots that were not found in the adult tree population is significant (48\% more species in 2015 in relation to initial levels; Table 2). Although this result can be partially attributed to neighboring trees not included in the study area, the diversity of species (which are mainly dispersed by zoochory) may be related to the movement of birds and other animals across the landscape (COLORADO et al., 2018). Our results indicate that in areas with caivas located within relatively short distances from each other $(<1 \mathrm{~km})$, anthropogenic forest fragmentation has not impeded successful seed dispersion for trees species.

As a silvopastoral agroforestry system, caívas need to be recognized for their sociocultural and environmental benefits. Currently, income generation in caívas is constrained by low levels of animal production, erva-mate price fluctuation, and legal restrictions on forest management that have put the continuity of the system at risk (MELLO and PERONNI, 2015; HANISCH et al., 2016). Small-scale farmers are facing mounting pressure to transition towards monoculture plantations, such as commercial forests (pine) or annual crops (soy and corn), with the consequent losses in cultural and environmental benefits.

Along with the implementation of management practices that guarantee the long-term health of caíva forests, the adoption of techniques to improve pastures has also been cited as a vital step for their sustainability (HANISCH et al., 2016). The introduction of techniques widely used in silvopastoral systems have helped to improve animal productivity, such as pasture rotation, control of stocking rate, and introduction of alternative pasture species (HANISCH et al.,2016). Additionally, economic incentives, access to credit, and the establishment of payment for ecosystem services (PES) could help to strengthen the social and economic capital of caívas. Finally, it is important to emphasize that the improvement of these agroforestry systems and development of silvicultural practices must be supported through the direct involvement of communities and farmers. It is also necessary for policy-makers to include small-scale farming initiatives in government policies, representing a paradigm shift from the current focus on large-scale production of agricultural commodities.

FLORESTA, Curitiba, PR, v. 50, n. 3, p. 1537 - 1546, jul/set 2020.

Hanisch, A. L. et.al.

ISSN eletrônico 1982-4688

DOI: $10.5380 /$ rf.v50 i3. 64248 


\section{CONCLUSIONS}

- Forest management in the caiva modified the population structure mostly through the reduction in the density of a few adult tree species, particularly Ilex paraguariensis and Curitiba prismatica.

- Without the presence of animals and the practice of mowing, the caiva presents significant resilience for forest regeneration, despite the extractive use of these remnants over a long period of time;

- The forest richness was 21 species in the adult population and 37 in the forest regeneration, with only one exotic species, indicating the contribution of caivas to the conservation of species typical of the Araucaria Forest biome;

- Several species not found in the adult population were found in the regeneration population, demonstrating the presence of effective seed dispersal agents;

- After six years of isolation in the plots, a density of more than 8000 seedlings.ha ${ }^{-1}$ was found, confirming that this practice can be an important strategy for the management of these areas for environmental conservation.

\section{ACKNOWLEDGEMENTS}

This research was made possible through the financial and technical support of Epagri - Empresa de Pesquisa Agropecuária e Extensão Rural de Santa Catarina and Embrapa Forestry. We thank Miguel and Raquel Gurzynski for providing the area for this study and for their always helpful insights throughout the research. We would also like to thank Dr. Evelyn R Nimmo for language editing support.

\section{REFERENCES}

ANGIOSPERM PHYLOGENY GROUP. An update of the Angiosperm Phylogeny Group classification for the orders and families of flowering plants: APG IV. Botanical Journal of the Linnean Society, v.181, n.1, p 1-20, 2016.

BUDOWSKI G. Distribution of tropical American Rain Forest species in the light of successional processes. Turrialba, v.15, n.1. p. 40-42, 1965.

COLORADO, Z.G.J.; MEHLMAN, D.; VALENCIA, C.G. Effects of floristic and structural features of shade agroforestry plantations on the migratory bird community in Colombia. Agroforest Systems, v.92, p. 1-15, 2018.

COLWELL, R.K. Estimates: Statistical estimation of species richness and shared species from samples. Version 8.0. User`s Guide and application published at: http://purl.oclc.org/estimates. 2013.

DE LIOCOURT, F. De l'amenagements des sapinieres. Bulletin Trimestries, Société Foresstirere de FranceComté et Belfort, Julliet. 396-40, 1898.

FLORA do Brasil 2020 em construção. Jardim Botânico do Rio de Janeiro. Availabel at: http://floradobrasil.jbrj.gov.br/

FOOD AND AGRICULTURE ORGANIZATION [FAO]. http://www.fao.org/forestry/agroforestry/en/. 2016.

HANISCH, A.L.; RADOMSKI, M.I.; BONA, L.C.; MARQUES, A.C. Melhoria da produção animal em áreas de caíva e sua contribuição para a viabilização de corredores ecológicos. Desenvolvimento Regional em debate, v. 6, n.2, p. 170-188, 2016.

HANISCH, A.L.; VOGT, G.A.; MARQUES, A.C.; BONA, L.C.; BOSSE, D. Estrutura e composição florística de cinco áreas de caíva no Planalto Norte de Santa Catarina. Pesquisa Florestal Brasileira, v. 30, n.64, p. 303-310, 2010.

JOHNSTONE, J.F.; ALLEN, C.D.; FRANKLIN, J.F.; FRELICH, L.E.; HARVEY, B.J.; HIGUERA, P.E.; MACK, M.C.; MEENTEMEYER, R.K.; METZ, M.R.; PERRY, G.L.W.; SCHOENNAGEL, T.; TURNER, M.G. Changing disturbance regimes, ecological memory, and forest resilience. Frontiers in Ecology and the Environmental, v. 14, p. 369-378, 2016.

KANIESKI, M. R.; LONGHI, S.J.; NARVAES, I.S.; SOARES, P.R.C.; LONGHI-SANTOS, T.; CALLEGARO, R.M. Diversidade e padrões de distribuição espacial de espécies no estágio de regeneração natural em são Francisco de Paula, RS, Brasil. Floresta, v. 42, n. 3, p. 509-518, 2012.

LACERDA, A.E.B. Conservation strategies for Araucaria Forests in Southern Brazil: assessing current and alternative approaches. Biotropica, v. 48, n. 4, p. 537-544, 2016.

FLORESTA, Curitiba, PR, v. 50, n. 3, p. 1537 - 1546, jul/set 2020

Hanisch, A. L. et.al.

ISSN eletrônico 1982-4688

DOI: 10.5380/rf.v50 i3. 64248 
LORENZI, H. Árvores Brasileiras: manual de identificação e cultivo de plantas arbóreas nativas do Brasil. v.2. Nova Odessa: Plantarum, 2014. 384 p

MELLO, A.J.M.; PERONI, N. Cultural landscapes of the Araucaria Forests in the Northern Plateau of Santa Catarina, Brazil. Journal of Ethnobiology and Ethnomedicine, v. 11, n. 51, p 1-14, 2015

MEYER, H.A. Structure, growth, and drain in balanced uneven-aged forests. Journal of Forestry, v. 50, n. 2, p. 85-92, 1952.

MEYER, L.; SEVEGNANI, L.; GASPER, A. L. de; SCHORN, L. A.; VIBRANS, A. C.; LINGNER, D. V.; VERDI, M.; SANTOS, A.S.; DREVECK, S.; KORTE, A. Regeneração natural da Floresta Ombrófila Mista em Santa Catarina. In: VIBRANS, A. C.; SEVEGNANI, L.; GASPER, A. L. de; LINGNER, D. V. Inventário Florístico Florestal de Santa Catarina, Vol. III, Floresta Ombrófila Mista. Blumenau: Edifurb, 2013, p.157189

MICHON, G.H.; FORESTA, H.; LEVANG, P.; VERDEAUX, F. Domestic forests: a new paradigm for integrating local communities' forestry into tropical forest science. Ecology and Society, v. 12, n. 2:1; 2007.

PIGNATARO, A.G.; TACHER, S.I.L.; RIVERA, J.R.A.; TORAL, J.N.; ESPINOSA, M.G.; CARMONA, N.R. Silvopastoral systems of the Chol Mayan ethnic group in southern Mexico: Strategies with a traditional basis. Journal of Environmental Management, v. 181, p. 363-373, 2016.

PINOTTI, L.C.A.; HANISCH, A.L.H.; NEGRELLE, R.R.B. The Impact of Traditional Silvopastoral System on the Mixed Ombrophilous Forest Remnants. Floresta e Ambiente, v. 25, n. 4, e201701922018; 2018.

REIS, M.S.; SILVA, C.V.; MATTOS, A.G.; ZECHINI, A.A.; MANTOVANI, A.; PERONI, N. Caívas and their contribution to the conservation of Atlantic forest landscapes in Brazil. In: Boef WS, Subedi A, Peroni N, Thijssen M, O'Keeffe E, publishers. Community Biodiversity Management: Promoting resilience and the conservation of plant genetic resources. Routledge, London, 2013.

SOUZA, I.F.; SOUZA, A.F.; PIZO, M.A.; GANADE, G. Using tree population size structures to assess the impacts of cattle grazing and eucalypts plantations in subtropical South America. Biodiversity Conservancy, v.19, p.1683-1698, 2010.

STUEPP, C. A.; BITENCOURT, J; ZUFFELLATO-RIBAS, K. C.; WENDLING, I.; KOEHLER, H. S. Indução de brotações epicórmicas por meio de anelamento e decepa em erva-mate. Ciência Florestal, v. 26, p. 1009, 2016.

TROPICOS. Missouri Botanical Garden. Disponível em: < http://www.tropicos.org $>$. Accessed on 22 January 2016

VIBRANS, A.C.; SEVEGNANI, L.; UHLMANN, A.; SCHORN, L.A.; SOBRAL, M.G.; DE GASPER, A.L.; LINGNER, D.V.; BROGNI, E.; KLEMZ, G.; GODOY, M.B.; VERDI, M. Structure of mixed ombrophyllous forests with Araucaria angustifolia (Araucariaceae) under external stress in Southern Brazil. Revista de Biología Tropical, v.59, n. 3, p. 1371-1387, 2011.

VIEIRA, D.L.M.; HOLL, K.D.; PENEIREIRO, F.M. Agro-Successional Restoration as a Strategy to Facilitate Tropical Forest Recovery. Restoration Ecology, v. 17, n. 4, p. 451-459, 2009. 